UDC 577

\title{
Functional complementation of a conserved non protein-coding element (CNE) of Autographa californica multiple nucleopolyhedrovirus by hetero- logous CNE originating from Malacosoma neustria nucleopolyhedrovirus
}

\author{
I. M. Kikhno, V. E. Makarenko, V. I. Kashuba \\ Institute of Molecular Biology and Genetics, NAS of Ukraine \\ 150, Akademika Zabolotnoho Str., Kyiv, Ukraine, 03680 \\ i.m.kikhno@imbg.org.ua
}

\begin{abstract}
Aim. To assess the functional conservation of a baculovirus CNE. Methods. CNE deletion from the baculovirus genome and its replacement with a heterologous CNE was performed by using the bacmid-based technology. Transfection-infection assays were used to investigate cell-to-cell spread of the recombinant virus. Results. The recombinant Autographa californica multiple nucleopolyhedrovirus genome carrying the Malacosoma neustria nuclepolyhedrovirus CNE in place of the innate CNE was constructed. The recombinant virus was able to transmit the infection in a cell culture. Conclusions. The CNE essential function was foundto be conserved between the representatives of I and II groups of the genus Alphabaculovirus.
\end{abstract}

Ke yw or d s: Baculovirus, baculovirus CNE, functional complementation

\section{Introduction}

Baculoviridae is the name of a family of enveloped, double-stranded DNA viruses infecting invertebrates. The family is specific in that its representatives form the inclusion bodies in infected cells. The shape of inclusion bodies (polyhedra or granules) formed by different viruses determines a predetermined baculovirus division onto nucleopolyhedroviruses (NPV) and granuloviruses (GV) respectively [1]. The family members are widely studied for various applications: besides the traditional recognition of baculoviruses as safe insecticides, the genetically modified representatives of the family are considered to be efficient expression vectors, vaccine producers and prospective gene therapy vectors [2]. Large and complex circular baculovirus genomes comprise up to 180 genes as well as non-coding functional elements, from which the transcriptional regulators and origins of replication of different kinds have been well studied [3]. The phylo- genetic relationships established among the family representatives have revealed the synchronous development of virus and host lineages over large evolutionary timespans [4]. This tendency is reflected in the modern baculovirus taxonomy according to which the family is divided into four genera, Alpha-, Beta-, Gama- and Deltabaculovirus comprising lepidopteran NPV, lepidopteran GV, hymenopteran NPV and dipteran NPV respectively [5]. A phylogenetic analysis also illustrates subdivision of the genus Alphabaculovirus onto group I and group II [6]. The representatives of two groups differ in an envelope protein that provides the fusion of a virus envelope with host membrane: gp64 serves as an identifier of group I, whereas $\mathrm{F}$ protein appears to be a marker of group II [7]. To date, more than 70 baculovirus genome sequences have been determined. A homology search approach applied for the analysis of the content of diverse baculovirus genomes has allowed the interpretation of each genome element as that mediating

(C) 2016 I. M. Kikhno et al.; Published by the Institute of Molecular Biology and Genetics, NAS of Ukraine on behalf of Biopolymers and Cell.

This is an Open Access article distributed under the terms of the Creative Commons Attribution License (http://creativecommons.org/licenses/by/4.0/),

which permits unrestricted reuse, distribution, and reproduction in any medium, provided the original work is properly cited 
ubiquitous, lineage-specific, or specie-specific function. Recently, by using this approach a conserved non protein-coding element (CNE) 154-156 bp in length has been identified in all alphabaculovirus genomes sequenced to date [8]. This alphabaculovirus-specific element was shown to be indispensable for the life cycle of Autographa californica multiple nucleopolyhedrovirus (AcMNPV), the prototype of Alphabaculovirus genus. The CNE essential function was shown not to be related either to CNE coding capacity (CNE overlaps short ORF and several non protein-coding RNA genes in AcMNPV genome), or to its activity as a transcriptional activator of the adjacent gene ie2. CNE is characterized by an extreme level of nucleotide conservation. This makes it different from other baculovirus non-coding elements because the latter evolve much faster during virus evolution. The $\mathrm{CNE}$ essential function has not yet been defined as well as the nature of CNE extreme conservation remains unknown. As noted above, CNE appears to be polyfunctional element and its conservation within the genus Alphabaculovirus points to the fact that at least some of CNE function(s) should be common for the genus members. Accordingly, the below-described experiment was designed to test whether as yet unknown essential function is shared by representatives of the genus. The replacing of the AcMNPV CNE with its Malacosoma neustria nuclear polyhedrosis virus (ManeNPV) equivalent revealed functional conservation of this element despite the relatively high evolutionary distances between two viruses (AcMNPV and ManeNPV belong to alphabaculovirus groupI and groupII respectively [9]). These results provide the support for the suggestion that the CNE essential function specifies the genus Alphabaculovirus.

\section{Materials and Methods}

\section{Bacmids, viruses, cell lines}

Recombinant AcMNPV genomes, derivatives of the original bacmid bMON14272 [10] were maintained in E. coli cells DH10B.

The Sf9 cell line originated from the AcMNPV natural host, fall armyworm, Spodoptera frugiperda was used in the transfection-infection experiments. The MCA cell line derived from the Chinese tasar moth Antheraea pernyi was used for the propagation of ManeMNPV. Cells were cultured in TC100 medium (Sigma Aldrich) supplemented with $10 \%$ fetal bovine serum, penicillin $(100 \mathrm{U} / \mathrm{ml})$, streptomycin $(100 \mu \mathrm{g} / \mathrm{ml})$ and amphotericin $(2.5 \mu \mathrm{g} / \mathrm{ml})$ at $27^{\circ} \mathrm{C}$.

\section{Purification of virus DNA, amplification of CNE-containing fragment}

ManeNPV DNA was purified from the infected cells using a standard phenol-chlorophorm extraction procedure as described [11]. The amplification of the ManeNPV CNE from the ManeNPV DNA template was carried out with the primers derived from the regions surrounding the CNE in ManeNPV genome: MnD 5'CGGAATTCAGGAATAGATAACGAAC-3' and MnR 5'-GCGGATCCCAAAATGCGTCATGG AA-3'.

\section{Recombinant virus construction}

CNE knock out bacmid vAcCNE-Ko obtained earlier [8] was used for the construction of the CNE repaired bacmid, where the genuine AcMNPV CNE was replaced by the CNE of ManeNPV. The insertion of ManeNPV CNE in the particular position of vAc CNE-Ko was performed by using commercially available Bac-to-Bac system (Invitrogen) according to the manufacturer instruction. Briefly, the amplified ManeNPV CNE-containing fragment was cloned into BstI site of pFastBac-Dual-EGFP, the recombinant plasmid represented by $\mathrm{pFastBac-Dual}$ with green fluorescent protein gene inserted under the control of polyhedrin promoter. The EGFP-CNEcontaining cassette was transposed into $\mathrm{vAc}^{\mathrm{CNE}-\mathrm{Ko}}$ propagated in $\mathrm{DH} 10 \mathrm{~B}$ through the cell transformation with resulting transfer vector $\mathrm{pFastBac}$-DualCNE-EGFP followed by homologous recombination. The resulting recombinant bacmid $\mathrm{vAc}^{\mathrm{CNE}-\mathrm{Ko}-}$ RepMane-EGFP as well as bacmids used as controls were purified as described by Bac-to-Bac manufacturer.

\section{Transfection, infection procedures}

DOTAP transfection reagent (Sigma-Aldrich) was used to introduce bacmid DNA into Sf9 cells. $3 \mu 1$ 
DOTAP and $1 \mu \mathrm{g}$ bacmid DNA were mixed with $100 \mu 1$ and $150 \mu 1$ of HBS buffer respectively, after that two suspensions were combined. After the incubation for $30 \min 350 \mu 1$ of TC100 medium without antibiotics were added to the DNA-DOTAP complex and the resulting mixture was layered onto the cell monolayer $\left(1 \times 10^{6}\right.$ cells per $30 \mathrm{~mm}$ dish).

After 96 hours the post transfection (hpt) supernanants were harvested. $100 \mu l$ aliquots were used for the infection of fresh monolayers on $30 \mathrm{~mm}$ dishes.

The efficiency of transfection/infection was monitored by the fluorescent microscopy.

\section{Results}

\section{Replacement of the original AcMNPV CNE by the heterologous $C N E$}

Replacement of the genome element by its homolog originated from a heterologous genome followed by functional studies is a widely used method to test the functional conservation/diversification of these elements in the course of evolution. AcMNPV and
ManeNPV which appear to be the representatives of Alphabaculovirus groupI and groupII respectively were chosen as a subject of investigation aimed to test the functional conservation of CNE between two lineages of the genus. It is notable that AcMNPV efficiently disseminates the infection from cell to cell in the SF9 cell culture. In contrast, ManeNPV was shown not to be able to infect the Sf9 cells, that was an important factor enabling the design of functional complementation experiment.

The CNE knock out bacmid vAcCNE-Ko-EGFP as well as vAc CNE-Ko-Rep-EGFP, the CNE repair bacmid which contains its own CNE in heterologous location (9 $\mathrm{kb}$ away from the original position) were obtained earlier [8]. It was shown that while vAc CNE-Ko-EGFP is not able to spread the infection from cell to cell, the CNE repaired virus efficiently does it, so these bacmids were used as controls in the experiment described below. The CNE deletion mutant $\mathrm{vAc}^{\mathrm{CNE}-\mathrm{Ko}}$ was used for the construction of the second CNE repaired bacmid which represents the analog of $\mathrm{vAc}^{\mathrm{C}-}$ NE-Ko-Rep-EGFP, where the genuine AcMNPV CNE was

bMON14272

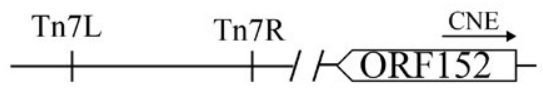

$\mathrm{VAc} \mathrm{c}^{\mathrm{CNE}-\mathrm{Ko}-\mathrm{EGFP}}$

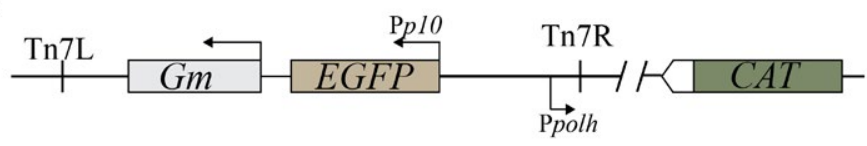

$\mathrm{VAc} \mathrm{c}^{\mathrm{CNE}-\mathrm{Ko}-\mathrm{REP}-\mathrm{EGFP}}$



$\mathrm{VAc}^{\text {CNE-Ko-REPMane-EGFP }}$

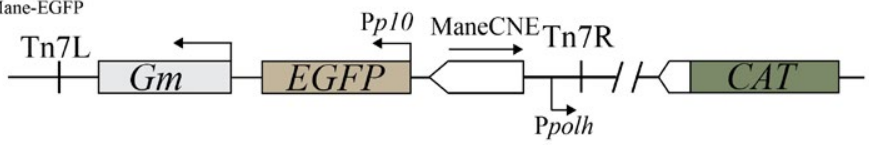

Fig. 1. Comparative presentation of the organization of analogous CNE-containing genome regions of the parental bacmid bMON14272 and its derivatives, CNEknockout and CNE-repaired bacmids.

Recombinant genomes vAc CNE-Ko and vAcCNE-Ko-REP-EGFP were derived earlier [8]. Bacmid vAcCNE-KO was used for generation of the CNE-repaired mutant vAcCNE-KO-REPMane-EGFP carrying heterologous CNE originated from ManeNPV genome. vAcCNE-KO-REPMane-EGFP was a result of the insertion of gentamicin-resistance gene $(\mathrm{Gm})$ - EGFP gene - ManeNPV CNE cassette into the polyhedrin (polh) locus of vAc ${ }^{\mathrm{CNE}-\mathrm{KO}}$ via transposon-mediated recombination using Bac-to-Bac system (Invitrogen Life Technologies). Tn7L and Tn7R indicate the left and right transposon arms, respectively. Arrows labeled Pp10 and Ppolh, denote the polh and $p 10$ promoters, respectively, and the unlabeled arrows denote native gene promoters. The arrowed white boxes indicate the complete and truncated Orf152, the black arrow above the boxes specifies CNE location within Orf152. 
replaced by the CNE of ManeNPV (Fig. 1). The resulting recombinant $v A c^{C N E-K o-R e p M a n e-E G F P ~ a l s o ~ c o n-~}$ tained the EGFP gene which was inserted into the genome to simplify the detection of an infected cell using fluorescent microscopy. All construction manipulations were made using Bac-to-Bac system (see details in Material and Methods). vAc CNE-Ko-RepManeEGFP together with vAc CNE-Ko-EGFP (negative control) and $\mathrm{VAc}$ CNE-Ko-Rep-EGFP (positive control) were used for the subsequent transfection of the Sf9 cells.

\section{Transfection-infection assays}

To test the ability of AcMNPV carrying the ManeNPV CNE to be propagated in the Sf9 cells the transfection-infection assays were applied as de- scribed earlier [12]. The Sf9 cell monolayers formed by $1 \times 10^{6}$ cells per $30 \mathrm{~mm}$ cell culture dish were subjected to transfection by the vAcCNE-Ko-RepMane-EGFP, vAc CNE-Ko-EGFP and vAc CNE-Ko-Rep-EGFP. After 40 hours of incubation all cell monolayers were inspected by the fluorescent microscopy to estimate the transfection efficiency. The transfection efficiency was revealed to be quite comparable for each of transfected monolayers: nearly $10 \%$ of cells in each monolayer illuminated with ultraviolet light emitted fluorescence. At $96 \mathrm{hpt}$ the same amount of cells emitting

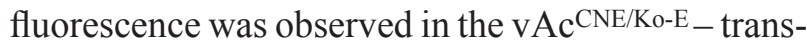
fected sample but not in the samples transfected with

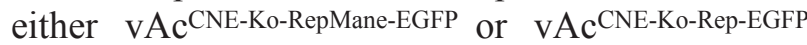
where amount of cells emitting green light increased

\section{TRANSFECTION}
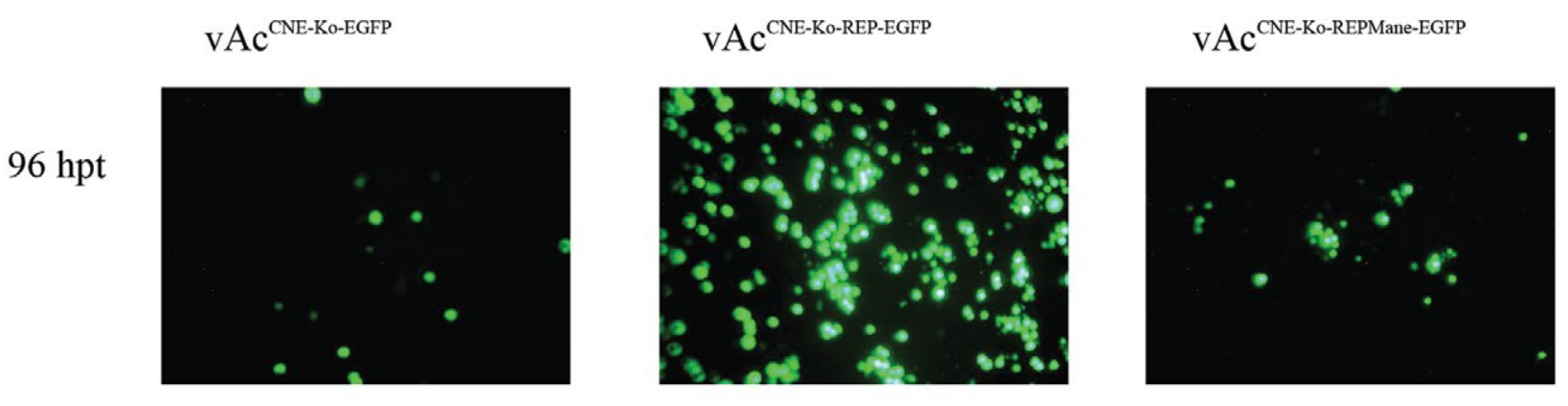

\section{INFECTION}
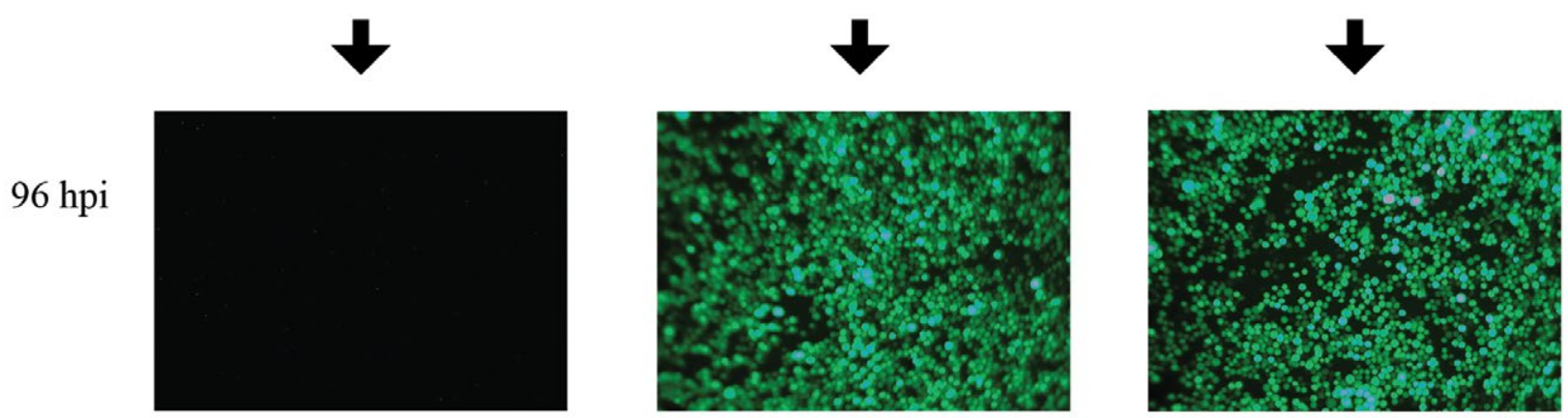

Fig. 2. Analysis of the infectivity of vAc ${ }^{\mathrm{CNE}-K O-E G F P}$, vAc ${ }^{\mathrm{CNE}-K O-R E P-E G F P}$, vAc ${ }^{C N E-K O-R E P M a n e-E G F P}$.

Cells transfected with DNA from indicated constructs (the top row of the image) and cells inoculated with the supernatants harvested from transfected cells (the bottom row of the image). Images were captured at 96 hpt and 96 hpi. 
significantly (Figure 2). It is notable, however, that the $\mathrm{vAc}$ CNE-Ko-Rep-EGFP and vAc CNE-Ko-RepMane-EGFP_ transfected monolayers were different in respect of the amount of green cells detected by the fluorescent microscopy: while the great majority of cells emitted fluorescence in the former, the discrete green islands formed by the cells surrounding the primarily transfected cell were visible in the latter. These data suggest that the ManeNPV CNE can rescue the lethal phenotype of AcMNPV carrying the CNE disruption, although the reduced amount of vAcCNE-Ko-RepMane-EGFP - infected cells in comparison with the amount of VAcCNE-Ko-Rep-EGFP - infected cells points that the ManeNPV CNE functions less efficiently than the original CNE. To further support these data the supernatants from transfected cells were harvested and used subsequently for the infection of fresh monolayers. At $96 \mathrm{hpi}$ nearly $100 \%$ of $\mathrm{vAc}$ CNE/KoRepMane-EGFP - and vAcCNE-Ko-Rep-EGFP - infected cells exhibited green emission. No fluorescence emission was observed in the cell monolayers inoculated by the vAc CNE-Ko-EGFP supernatant. These data were in accordance with the above suggestion about the conservation of $\mathrm{CNE}$ essential function between viruses.

\section{Discussion}

The nature of extended conservation of the CNE sequence across the genus Alphabaculovirus remains unknown, herewith, two non-mutually exclusive possibilities may be considered. A slow evolutionary rate of the CNE sequence may be caused by the overlap of several functional elements in the CNE locus, as well as may be the reflection of the intrinsic feature of some peculiar functional unit attributed to the CNE (Discussed in [8]). To clarify this issue, it is of great importance not only to establish so far unknown CNE function(s), but also to determine whether the essential or/and non-essential CNE functions remain conserved across the genus Alphabaculovirus. The fact of vital importance of the former for AcMNPV suggests a high but not absolute probability of its conservation among alphabaculoviruses, as can be deduced by analogy with the polyfunctional proteins: for instance, the $\mathrm{F}$ protein gene is found in the genomes of repre- sentatives of all baculovirus genera, however $\mathrm{F}$ protein is expected to play an essential role of a fusion protein only in group II alpha-, beta- and deltabaculoviruses. In group I viruses, it appears to be inactive as a fusion protein and have been replaced by gp64 ([13] and references herein). Proceeding from it, the complementation experiment was designed to test the conservation of the CNE essential function between the relatively distant alphabaculoviruses, AcMNPV and ManeNPV, the representatives of alphabaculovirus groupI and groupII respectively. It was shown that the ManeNPV CNE can functionally substitute for the AcMNPV CNE that is in accordance with the assumption about the CNE essential function specifying the alphabaculovirus genus. Herewith, a decrease in the infectivity of vAcCNE-Ko-RepMane-EGFP observed in the experiment points that the $\mathrm{CNE}$ activity is the characteristic of a particular virus species in respect of its efficiency which depends on the specific conditions provided by the virus or/and host cell. It is worth emphasizing that the replacement of the CNE in het-

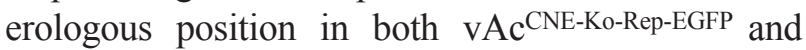
vAcCNE-Ko-RepMane-EGFP genomes should lead to the loss of the CNE non-essential function, cis-regulation of the expression of an adjacent gene as well as its coding capacity of short peptide and ncRNAs, therefore the above conclusion is assigned precisely to the CNE essential activity.

An earlier comparative analysis of the alphabaculovirus genomes have demonstrated that the peptidecoding capacity of CNE is not universal and the vast majority of the alphabaculovirus CNEs do not overlap with any ORFs [8]. Conservation of the CNE essential function between relatively distant alphabaculoviruses has been demonstrated by the present study. Conservation/diversification of both CNE cisregulatory activity and $\mathrm{CNE}$ capacity to encode ncRNA remains to be established in order to infer the nature of the extraordinary conservation of CNE.

\section{REFERENCES}

1. Herniou EA, Arif BM, Becnel JJ, Blissard GW, Bonning B, Harrison R, Jehl JA, Theilmann DA, Vlak JM. Family Baculoviridae. In: King AMQ, Adams MJ, Carstens EB, Lefkow- 
itz EJ. Virus Taxonomy: Ninth Report of the International Committee on Taxonomy. Elsevier Inc. 2011:163-74.

2. Felberbaum RS. The baculovirus expression vector system: A commercial manufacturing platform for viral vaccines and gene therapy vectors. Biotechnol J. 2015;10(5):702-14.

3. van Oers MM, Vlak JM. Baculovirus genomics. Curr Drug Targets. 2007;8(10):1051-68.

4. Rohrmann GF, Pearson MN, Bailey TJ, Becker RR, Beaudreau GS. N-Terminal polyhedrin sequences and occluded Baculovirus evolution. J Mol Evol. 1981;17(6):329-33.

5. Jehle JA, Blissard GW, Bonning BC, Cory JS, Herniou EA, Rohrmann GF, Theilmann DA, Thiem SM, Vlak JM. On the classification and nomenclature of baculoviruses: a proposal for revision. Arch Virol. 2006;151(7):1257-66.

6. Zanotto PM, Kessing BD, Maruniak JE. Phylogenetic interrelationships among baculoviruses: evolutionary rates and host associations. J Invertebr Pathol. 1993;62(2):147-64.

7. Pearson MN, Rohrmann GF. Transfer, incorporation, and substitution of envelope fusion proteins among members of the Baculoviridae, Orthomyxoviridae, and Metaviridae (insect retrovirus) families. J Virol. 2002;76(11):5301-4.

8. Kikhno I. Identification of a conserved non-protein-coding genomic element that plays an essential role in Alphabaculovirus pathogenesis. PLoS One. 2014;9(4):e95322.

9. Bulach DM, Kumar CA, Zaia A, Liang B, Tribe DE. Group II nucleopolyhedrovirus subgroups revealed by phylogenetic analysis of polyhedrin and DNA polymerase gene sequences. J Invertebr Pathol. 1999;73(1):59-73.

10. Luckow VA, Lee SC, Barry GF, Olins PO. Efficient generation of infectious recombinant baculoviruses by site-specific transposon-mediated insertion of foreign genes into a baculovirus genome propagated in Escherichia coli. J Virol. 1993;67(8):4566-79.

11. O'Reilly DR, Miller LK, Luckow VA. Baculovirus expression vectors: A laboratory manual Oxford University Press. 1993; $368 \mathrm{p}$.

12. Lin G, Blissard $G W$. Analysis of an Autographa californica nucleopolyhedrovirus lef-11 knockout: LEF-11 is essential for viral DNA replication. J Virol. 2002;76(6):2770-9.

13. Wang $M$, Wang J, Yin F, Tan Y, Deng F, Chen X, Jehle JA, Vlak JM, Hu Z, Wang $H$. Unraveling the entry mechanism of baculoviruses and its evolutionary implications. $J$ Virol. 2014;88(4):2301-11.

Функціональна комплементація консервативного некодуючого элементу (CNE) вірусу ядерного полиедрозу Autographa californica гетерологічним CNE з віруса ядерного поліедрозу Malacosoma neustria

I. М. Кіхно, В. Е. Макаренко, В. І. Кашуба

Мета. Оцінити функціональну консервативність бакуловірусного CNE (conserved non protein-coding element).
Вивчити функціональне заміщення консервативного некодуючого елемента (CNE) вірусу ядерного поліедроза Autographa californica на CNE вірусу ядерного поліедрозу Malacosoma neustria. Методи. Видалення CNE з вірусного генома і його заміщення гетерологічним CNE було виконано $з$ використанням бакмідной технології. Трансфекційноінфекційний аналіз був застосований для дослідження поширення рекомбінантного вірусу від клітини до клітини. Результати. Було сконструйовано рекомбінантний геном віруса ядерного поліедрозу Autographa californica, що несе в своєму складі CNE віруса ядерного поліедрозу Malacosoma neustria замість власного CNE. Показано, що рекомбінантний вірус здатний передавати інфекцію в культурі клітин. Висновки. Абсолютно обов'язкова функкція $\mathrm{CNE} \epsilon$ консервативною для представників I і II груп роду Alphabaculovirus.

К л юч о в і с л о в а: бакуловірус, бакуловірусний CNE, функціональна комплементація

Функциональная комплементация консервативного некодирующего элемента (CNE) вируса ядерного полиэдроза Autographa californica гетерологичным CNE из вируса ядерного полиэдроза Malacosoma neustria

И. М. Кихно, В. Е. Макаренко, В. И. Кашуба

Цель. Оценить функциональную консервативность бакуловирусного CNE (conserved non protein-coding element). Методы. Удаление CNE из вирусного генома и его замещение гетерологичным CNE было выполнено с использованием бакмидной технологии. Трансфекционно-инфекционный анализ был применен для изучения распространения рекомбинантного вируса от клетки к клетке. Результаты. Был сконструирован рекомбинантный геном вируса ядерного полиэдроза Autographa californica, несущий в своем составе $\mathrm{CNE}$ вируса ядерного полиэдроза Malacosoma neustria вместо собственного CNE. Было показано, что рекомбинантный вирус способен передавать инфекцию в культуре клеток. Выводы. Абсолютно обязательная функция CNE является консервативной для представителей I и II групп рода Alphabaculovirus.

Кл юче в ы е сл ов а: бакуловирус, бакуловирусный CNE, функциональная комплементация 